\section{Sanitary Engineering}

\section{Graduate Degrees}

\section{Awarded in 1956}

\author{
Frederick K. Erickson, S.M.,
} and Frank A. Butrico, M.S.S.E.

$\mathbf{I}^{\mathrm{N}}$ the academic year 1955-56, 133 graduate degrees were conferred in the United States in the field of sanitary engineering, 12 fewer than in 1954-55. Of this total, 124 were master's and 9 doctor's degrees, granted in August 1955, February 1956, and June 1956. A total of 208 completed undergraduate sanitary engineering courses.

Institutions conferring sanitary engineering degrees are listed in the accompanying table with the number of degrees conferred. A list of all schools offering such training is available from the authors. Similar data for the period since 1889 are available in the literature (1-3) or have been distributed by the Public Health Service.

\section{Undergraduate Degrees}

Undergraduate sanitary engineering training was offered by 53 institutions. Of these, 32 reported graduates who had received "undergraduate training toward the bachelor's degree in sanitary engineering or with sanitary engineering major or option." For the academic years 1952-53, 1953-54, and 1954-55, the number of undergraduate degrees were 216,164 , and 141 , respectively. The bulk of the increase during 1955-56 over the previous academic year is represented by two schools reporting a total of 63 graduates this year but which reported none in the 1954-55 survey.

Mr. Erickson is sanitary engineer director, and $\mathbf{M r}$. Butrico is chief, Office of Engineering Resources, Division of Sanitary Engineering Services, Public Health Service.
The average number of graduates per year for the previous 10-year period $1946-55$ was 181 and for the 5-year period 1951-55, it was 196.

\section{Master's Degrees}

Of the 124 master's degrees awarded in the 1955-56 academic year, 93 were awarded to citizens of the United States, a decrease of 7 percent from the number in 1954-55. Graduate sanitary engineering training at the master's level was available in 67 universities or colleges, of which 34 reported no such degrees awarded this year. For the academic years 1952-53, 1953-54, and 1954-55, the numbers of master's degrees awarded were 102 (20 to foreign nationals), 120 (25 to foreign nationals), and 134 (34 to foreign nationals). The average number of master's degrees conferred per year for the 10-year period 1946-55 was 126, and for the 5-year period 1951-55, 122 .

\section{Doctor's Degrees}

Seven institutions awarded a total of 9 doctor's degrees, all but one to citizens of the United States. Doctoral training was available at 20 other institutions which reported no award of doctoral degrees. For the academic years 1952-53, 1953-54, and 1954-55, the numbers of graduates receiving doctor's degrees were 5 ( 3 foreign nationals), 9 (no foreign nationals), and 11 (2 foreign nationals), respectively. In the 10-year period 1946-55 the average number of doctor's degrees conferred per year was 5.6, and for the 5-year period 195155 , the average was 8.2 .

\section{REFERENCES}

(1) Miller, Arthur P.: Graduates from undergraduate sanitary engineering courses in the United States. Pub. Health Rep. 66 : 369-374, Mar. 23, 1951.

(2) Laubusch, E. J., and Ludwig, H. F.: Sanitary engineering degrees awarded in 1955. Pub. Health Rep. 71 : 945-946, September 1956.

(3) Miller, A. P.: Sanitary engineering degrees given in 1954. Pub. Health Rep. $70:$ 1039-1040, October 1955 . 


\begin{tabular}{|c|c|c|c|c|c|c|c|}
\hline Institution & $\begin{array}{l}\text { Doc- } \\
\text { tor's }\end{array}$ & $\begin{array}{l}\text { Mas- } \\
\text { ter's }\end{array}$ & $\begin{array}{l}\text { Bache- } \\
\text { lor's }\end{array}$ & Institution & $\begin{array}{l}\text { Doc- } \\
\text { tor's }\end{array}$ & $\begin{array}{l}\text { Mas- } \\
\text { ter's }\end{array}$ & $\begin{array}{c}\text { Bache- } \\
\text { lor's }\end{array}$ \\
\hline Alabama Polytechnic Institute & & $\mathbf{0}$ & 2 & Missouri, University of & & 0 & 5 \\
\hline $\begin{array}{l}\text { Alabama, University of } \\
\text { Arizona, University of }\end{array}$ & & 0 & 0 & Nebraska, University of & & $\mathbf{0}$ & \\
\hline $\begin{array}{l}\text { Arrzona, University of } \ldots \ldots \ldots \\
\text { Arkansas, University of } \ldots \ldots \ldots\end{array}$ & & & 0 & $\begin{array}{l}\text { New Hampshire, University of } \\
\text { Newark College of Engineering }\end{array}$ & & $\mathbf{0}$ & \\
\hline California Institute of Tech- & & & & New Mexico College of Agricul- & & 3 & \\
\hline $\begin{array}{l}\text { nology } \\
\text { California, University of }\end{array}$ & 0 & ${ }^{13}$ & & tural and Mechanical Arts & & 0 & \\
\hline & 2 & ${ }^{1} 10$ & 5 & New York University $\ldots \ldots$ & 1 & 111 & 12 \\
\hline ern. & & & 0 & $\begin{array}{l}\text { North Carolina State College } \\
\text { North Carolina, University of } \ldots\end{array}$ & & $\begin{array}{l}2 \\
16\end{array}$ & \\
\hline Case Institute of Technology & & $\mathbf{0}$ & & North Dakota, University of & & 0 & 0 \\
\hline Cincinnati, Univers & & 0 & & Northeastern University & & 2 & \\
\hline Clemson Agricultural College - & & & 6 & $\begin{array}{l}\text { Northwestern Technological In- } \\
\text { stitute }\end{array}$ & & & \\
\hline $\begin{array}{l}\text { College of Agricultural and Me- } \\
\text { chanical Arts, Puerto Rico }\end{array}$ & & & 0 & $\begin{array}{l}\text { stitute }_{1} \\
\text { Ohio State University }\end{array}$ & $\begin{array}{l}\mathbf{0} \\
\mathbf{0}\end{array}$ & $\begin{array}{r}13 \\
0\end{array}$ & 0 \\
\hline Colorado, University of & & 1 & 4 & Oklahoma Agricultural and $\mathrm{Me}-$ & & & \\
\hline Conn & & $\mathbf{0}$ & & chanical $\mathrm{C}$ & $\mathbf{0}$ & ${ }^{1} 1$ & 2 \\
\hline Cornell Univer & 1 & $\mathbf{0}$ & $\mathbf{0}$ & Oklahoma, Uni & & 14 & 0 \\
\hline Florida, Unive & 0 & 2 & 2 & State College _. . . & $\mathbf{0}$ & 1 & \\
\hline George Washingtor & & & 0 & e University - & $\mathbf{0}$ & 12 & 12 \\
\hline Georgia Instit & & 0 & ${ }^{1} 10$ & Polytechnic Institute of Brooklyn & & 0 & $\mathbf{0}$ \\
\hline $\begin{array}{l}\text { Harvard Unive } \\
\text { Idaho, Univers }\end{array}$ & 1 & ${ }^{1} 11$ & $\mathbf{0}$ & Purdue U & 0 & ${ }^{12}$ & \\
\hline of $\mathrm{Technology}$ & 0 & $\begin{array}{l}\mathbf{0} \\
\mathbf{0}\end{array}$ & & $\begin{array}{l}\text { Rensselae } \\
\text { Rhode Isl }\end{array}$ & & 0 & 8 \\
\hline $\begin{array}{l}\text { Illinois Institute } \\
\text { Illinois, Universit }\end{array}$ & & 14 & 2 & $\begin{array}{l}\text { Rhode Is } \\
\text { Rutgers }\end{array}$ & & $\begin{array}{l}0 \\
2\end{array}$ & 3 \\
\hline Iowa State Colleg & $\mathbf{0}$ & 2 & $\overline{2}$ & Dakota State College & & 0 & $\dot{1}$ \\
\hline Iow & & 13 & 2 & Southern California, University of & -- & 1 & \\
\hline rsity $\ldots$ & ${ }^{1} 1$ & 15 & & Methodist University & & ${ }^{1} 1$ & \\
\hline Kansas State C & 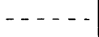 & & 29 & Stanford University $\ldots$ & & & $\mathbf{0}$ \\
\hline Kansas, Univer & & 0 & 2 & Tennessee, University of & & $\mathbf{0}$ & \\
\hline $\begin{array}{l}\text { Kentucky, Uni } \\
\text { Lehiyh Univers }\end{array}$ & & 0 & & Texas, Agricultural and Mechan- & & & \\
\hline $\begin{array}{l}\text { Lehiyh } \mathrm{C} \\
\text { Maine, } \mathrm{U}\end{array}$ & & 0 & $\begin{array}{l}\mathbf{0} \\
\mathbf{2}\end{array}$ & f-nen & $\mathbf{0}$ & 0 & \\
\hline Manhatt & & & $\begin{array}{r}2 \\
16\end{array}$ & al College $\ldots . .$. & & 0 & \\
\hline lette Univers & & & 0 & $\begin{array}{l}\text { ity of } \\
\text { sity of Louisiana }\end{array}$ & 0 & $\begin{array}{l}2 \\
0\end{array}$ & \\
\hline Massachusetts Institute of Tech- & & & & Utah, Unive & & $\mathbf{0}$ & \\
\hline nolo & 2 & 115 & 3 & Virginia Polytechnic Institute.... & $\mathbf{0}$ & 5 & 34 \\
\hline rsity of . . . & & 0 & 0 & Washington, State College of & & 12 & 2 \\
\hline Michigan State College & 0 & 1 & & IIniversity & & $\mathbf{0}$ & \\
\hline $\begin{array}{l}\text { Michigan College of Mining and } \\
\text { Technology }\end{array}$ & & 0 & 5 & $\begin{array}{l}\text { Washington, University of } \\
\text { West Virginia University }\end{array}$ & $\mathbf{0}$ & $\begin{array}{l}1 \\
0\end{array}$ & \\
\hline Michigan, University of - & 0 & 12 & 0 & Wisconsin, University of & 1 & 1 & 8 \\
\hline Minnesota, University of & 0 & ${ }^{1} 2$ & 0 & Wyoming, University of & & 0 & \\
\hline Missouri School of Mines and & & & & Total_ & 9 & 124 & 208 \\
\hline Metallurgy & & 0 & $\mathbf{I}$ & & & & \\
\hline
\end{tabular}

1 Includes foreign nationals.

Leaders (..... $)$ indicate no courses offered at this level. 


\section{PHS Films}

\section{Isolation and Identification of Beta-Hemolytic Streptococci}

35-mm. filmstrip, color, sound, $11 \mathrm{~min}$ utes, 94 frames. 1957.

Audience: Bacteriologists, laboratory technicians, and medical students.

This film is designed to show the techniques and procedures of isolating and identifying beta-hemolytic streptococci. It covers the preparation of blood agar pour-plates; procedures for isolating samples from swabs; identification of the organisms ; and procedures for isolating samples from Loeffler slants. It ends with a brief recapitulation.

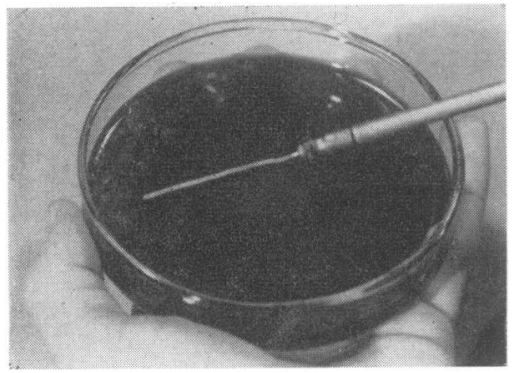

Streaking blood agar pour-plate with beta-hemolytic streptococci

\section{The Sanitary Landfill}

\section{Operating Procedures \\ II. Small Community Landfills}

35-mm. filmstrips, color, sound, $7 \mathrm{~min}-$ utes, 59 frames, and 6 minutes, 41 frames respectively, 1957 and 1956.

Audience: Sanifarians, municipal oficials, landfill equipment operators, and students of sanitary engineering.

Basic principles which apply to all landfills are stressed throughout part 1. Variations according to location-level sites, deep valleys, rolling terrain, marshy areas-and other determinants are demon-

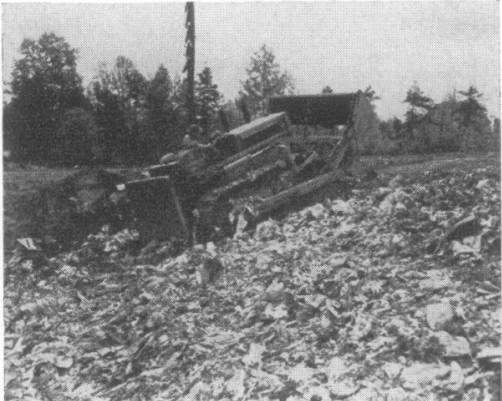

Compacting refuse in well-operated

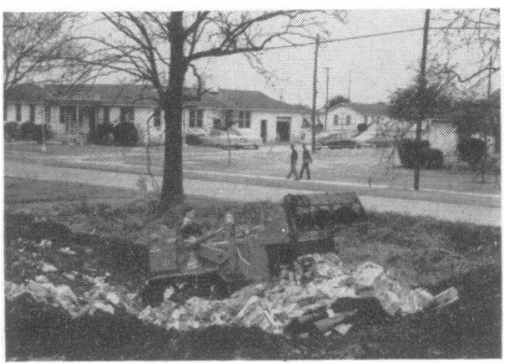

A sanitary landfill in operation in a small community

strated and accessory practices and equipment described.

The second part shows how the sanitary landfill can be adapted to small towns and communities. It features lightweight equipment in the several alternative practices presented.

\section{Rabies Control in the Community}

16-mm. fillmstrip, black and white, sound, 11 minutes, 405 feet, 1956.

Audience: Veterinarians, both public health and practicing.

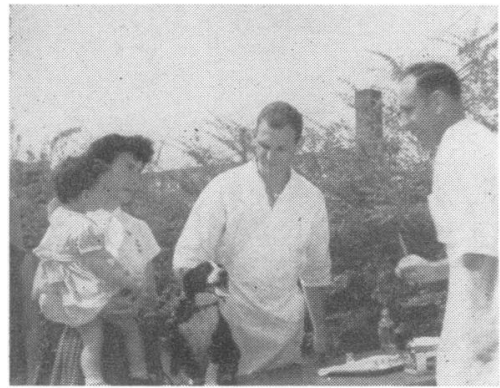

Primarily motivational, this film is not designed for technical training, for use in medical schools, or for TV. Instead it identifies rabies as a public health problem and outlines a three-point program for control on a community basis. The film shows actual cases of rabies in man and dog, how apathy of dog owners permits rabies to become a community problem, and concerted action to prevent rabies.

\section{Coccidioidomycosis- Its Epidemiological and Clinical Aspects}

16-mm. film, color, sound, $191 / 2$ minutes, 701 feet. 1957.

Audience: Professional medical personnel and mycological laboratory directors.

This film shows the distribution and ecology of the etiological agent, Coccidioides immitis; clinical aspects of the benign and disseminated

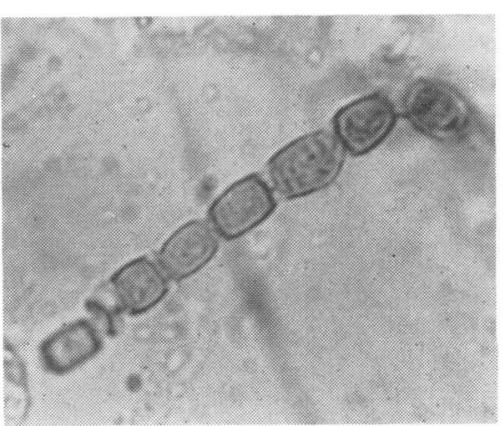

Chain of arthrospores typical of C. immitis.

forms through $\mathbf{X}$-ray films, actual cases and animation; variations in the symptomatology; histology ; serology; and laboratory procedures for isolation and identification of the fungus.

These films may be obtaincd on LOAN from the Communicable $\mathrm{Di}$ sease Center, Public Health Service, 50 \%th Street NE., Atlanta 5, Ga., or by PURCHASE from United World Films, Inc., 1445 Park Avenue, New York 29, N. Y. 